\title{
CLASSIFICATION OF FORMS OF SHADOW ECONOMIC ACTIVITY FROM THE VIEWPOINT OF ENSURING ECONOMIC SECURITY
}

\author{
Andrii Kubaienko' \\ Odessa State University of Internal Affairs, Ukraine
}

\begin{abstract}
The article explores the problem of economic security and its important institutional threat - the shadow economy. The evolution of approaches to the problem of the shadow economy, external and internal conditions of functioning of the shadow economy are considered. The shadow schemes, which are used by some business entities to evade taxes, are revealed. The research objective - to explore the evolution of approaches to the problem of the shadow economy as an institutional threat to economic security, to reveal shadow schemes, by which business entities for the purpose of tax evasion, propose a classification of the shadow economy that can be used by fiscal and supervisory bodies in developing practical measures to reduce the impact Shadow economy on the economic security of the state. The methodological and theoretical basis for the article is general scientific and special methods of the theory of knowledge: system analysis and synthesis (in the study of the essence and conceptual provisions of the theory of economic security), synergistic representations (in the study of the shadow economy), logical generalization and the complex goal approach shadow economic activity), the program-target approach (in the formation of measures to counteract the shadow economy). Suggestions for the classification of shadow economic activities that various economists propose vary considerably depending on the period of research, goals and tasks that the authors consider to approach. The article examines the existing approaches to the analysis of the shadow economy, systematizes the external and internal conditions of its existence, proposes a classification of ways to transfer resources to the shadow turnover at the level of the business entity. Schemes of tax evasion are considered as a way of transferring resources to the shadow economy. Unified schemes of tax evasion are considered as an integral element of the shadow economy, as well as shadow economic activity in areas not related to taxation. Based on the analysis of existing schemes for the transfer of economic activity into the shadow turnover, it is proposed to classify the methods of economic evasion from social norms, rules, and obligations. Practical implications. The application of the proposed classification will greatly simplify the information interaction between those structures that oppose the shadow economy; this will allow more purposeful implementation of counteraction to shadow economic transactions, which are institutional threats to economic security.
\end{abstract}

Key words: shadow economy, economic security, institutional threat, shadow turnover, doctrine of "business purpose".

JEL Classification: B40, B52, E62, H26

\section{Introduction}

The problem of ensuring the economic security and overcoming the shadow economy arose simultaneously with the emergence of new national interests in general and in economic ones in particular.

It is these processes that are taking place in Ukraine today. With varying degrees of urgency, this problem is relevant for many other countries, regardless of their level of economic development. But they become especially relevant in economic systems that function in the conditions of a deep transformational crisis. Under such conditions, the study of the issues of overcoming the threats to economic security is of great importance and testifies to the urgency of solving the existing problems faced by economists-practitioners, leaders, scientists, and the government.

The shadow economy is an institutional threat to the economic security of Ukraine, the depth of research of this problem requires a detailed classification of this ambiguous phenomenon.

Relevant scientific researches and issues analysis. Questions of economic security and the classification of forms of shadow economic activity are considered in a number of works of foreign and domestic scientists, such as Z. Gerasimchuk, O. Golovchenko, A. Danilian, V. Zakharchenko, V. Kizim, T. Klebanova, E. Kovalev,

Corresponding author:

${ }^{1}$ Department of Administrative Activities and Economic Security, Odessa State University of Internal Affairs.

E-mail: kav1312@ukr.net 
T. Kovalchuk, G. Pasternak-Tarnaushenko, R. Sitnik, M. Chumak, V. Shlemko, G. Becker, K. Boulding, G. Grossman, J. Buchanan, A. Katsenelinboigen, M. Olson, A. Portes, H. de Soto, J. Ubarra, E. Feige, K. Hart, and others.

Defining uninvestigated aspects of the general condition. Suggestions for the classification of shadow economic activities that various economists propose vary considerably depending on the period of research, goals and tasks that the authors consider to approach.

The research objective is: a) to explore the evolution of approaches to the problem of the shadow economy as it is an institutional threat to economic security; b) to reveal shadow schemes, which two business entities can resort to for the purpose of tax evasion; c) to propose a classification of the shadow economy that can be used by fiscal and supervisory bodies in developing practical measures to reduce the impact of the shadow economy on the economic security of the State.

The methodological and theoretical basis for the article is general scientific and special methods of the theory of knowledge: system analysis and synthesis (in the study of the essence and conceptual provisions of the theory of economic security), synergistic representations (in the study of the shadow economy), logical generalization and the complex goal approach shadow economic activity), the program-target approach (in the formation of measures to counteract the shadow economy).

\section{Types of the shadow economy}

Often researchers (Gerasimchuk, Vavidyuk, 2006), (Golovanov, Perekislov, Fadeyev, 2003), (Golovin,1992), (Zlupko, 1996), (Grossman, 1977) analyse two types of existence of the shadow economy: the shadow economy of the first type is an independent sector of the economy with an individual production function that differs from the legal economy, while the second type deals with a hidden aspect.
This type of shadow economy is mainly typical for the command and administrative system and for the economy of poor countries, in a number of cases it can be observed in a developed market economy, for example, when describing the shadow market of foreign currency, as well as a number of other goods and services, the turnover of which is strictly regulated by the state. According to G. Grossman (1977), the determining influence on the development of shadow markets is an exaggerated demand for goods and services. In his study, K. Boulding (1947) goes further, he believes that the size of the offer directly depends on the value of additional costs, namely penalties, and the offer price is the less, the higher the penalties for consumers.

The second type of shadow economy is observed in the market environment and represents a hidden version of the legal economy with an identical production function. The difference lies in the external social environment, which under the influence of a number of factors forms a number of conditions for the functioning of shadow activities (Tab. 1). For the purpose of investigating the manifestations of the shadow economy, such as that which is subject to taxation, we classify the ways of transferring resources to the shadow turnover. The classification is based on the model of the functioning of a business entity in the business environment (Fig. 1). Depending on the stage of the economic activity process, it is possible to identify ways of transferring resources into the shadow turnover that arise in the production process, as well as in the implementation of input and output commodity and financial flows.

For the purposes of investigating the behaviour of the shadow economy, as an economy, which is a threat to economic security and has acquired the character of a non-legal social institution (Tarasova, 2014), and is not also subject to taxation, we have classified the methods of transferring resources to the shadow economy. The classification is based on a business model of a business entity in its business environment (Figure 1).

In cases where the shadow activity of a subject is identified by any person, the reporting details of the

Table 1

External and internal functioning conditions of shadow and legal economy

\begin{tabular}{|c|c|c|}
\hline Operating Conditions & Shadow Economy & Legal Economy \\
\hline Information availability & Maximally closed & $\begin{array}{l}\text { Frankness of information } \\
\text { (with the exception of information that carries } \\
\text { commercial secrets) }\end{array}$ \\
\hline Temporary orientation & Oriented to short-term development & Oriented to long-term development \\
\hline $\begin{array}{l}\text { The nature of communication between } \\
\text { participants }\end{array}$ & Mainly locally oriented connections & Global connections (designed for many users) \\
\hline Social security of participants & None & Guaranteed by the country \\
\hline Legal support & Determined by participants & Determined by the country \\
\hline Currency & Dirty money, barter & Cashless funds and hard currency \\
\hline Risk assessment & $\begin{array}{l}\text { Increased risks associated with the possibility } \\
\text { of being revealed by the controllers }\end{array}$ & $\begin{array}{l}\text { Standard risks caused by such a type activity and } \\
\text { socio-economic condition of the environment }\end{array}$ \\
\hline
\end{tabular}

Source has been elaborated by the author 
economic entity identify the forfeit amounts or the reimbursement of losses that arise due to non-fulfilment of obligations.

Transferring resources into the shadow economy with tax evasion is carried out through tax evasion schemes. In order to determine uniquely what actions of economic entities fall under this concept, it is necessary to consider the doctrine of "business purpose".

The doctrine of the "business purpose" is that the operation consisting in reducing taxes and not any other economically justified or management purpose can be declared invalid. The determination of the existence of reasonable economic or any other reasons in the actions of the taxpayer is carried out taking into account the assessment of circumstances that indicate his intention to obtain an economic effect as a result of real business or any other economic activity. Any operation should have any commercial purpose, that is, the direction for profit, which is the meaning of the entrepreneurial activity.

Taking into account that it is not obligatory, an operation should have a direct aim of obtaining profit. Basically, this is usually the case, but the commercial goal which is profit can sometimes be achieved in the chain of operations, some of which can even be planned as unprofitable. For instance, a taxpayer may sell goods

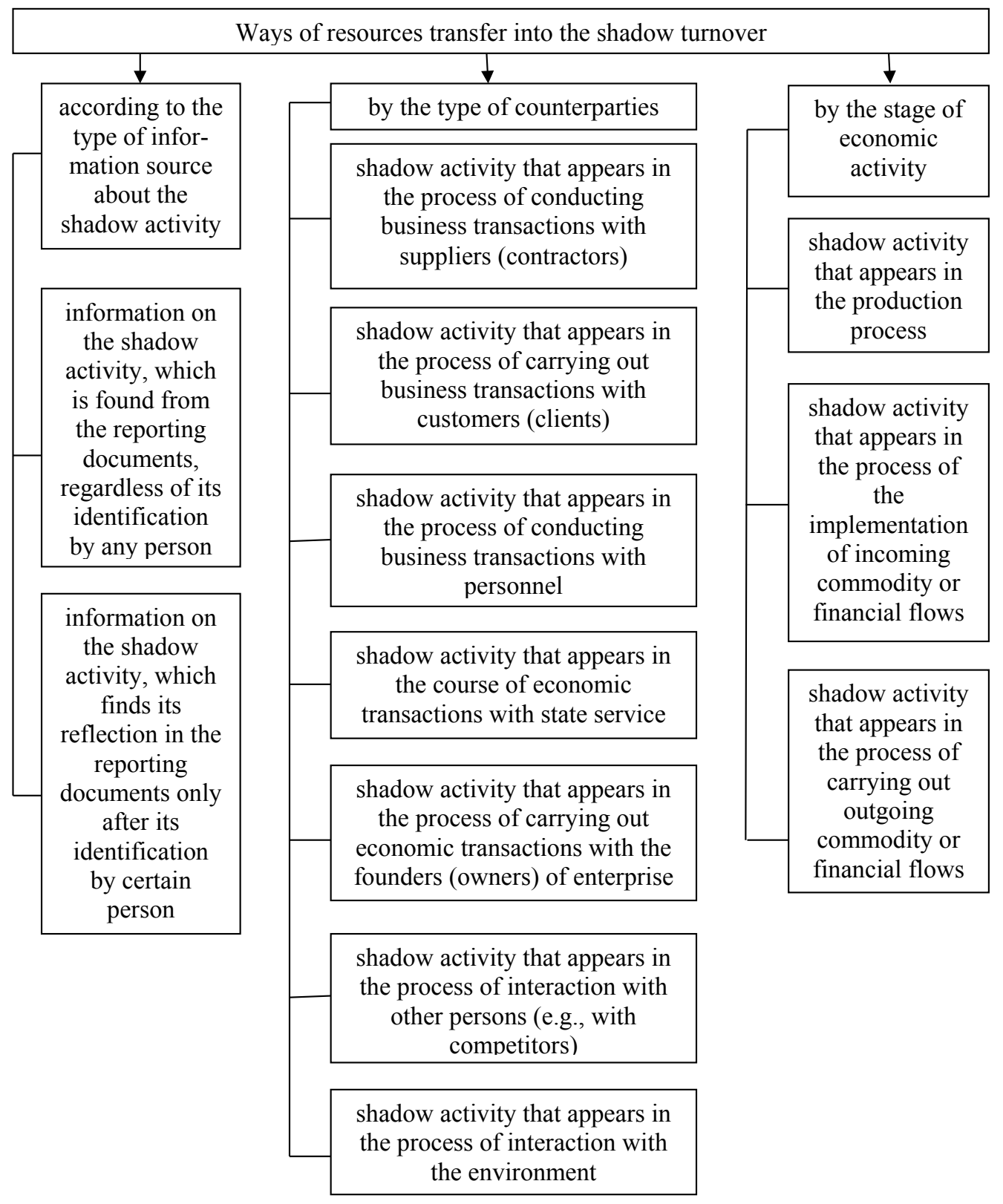

Fig. 1. Classification of ways to transfer resources into the shadow turnover at the level of the business entity Source has been elaborated by the author 
below the market value in order to capture a particular market segment and promote a new product. In this case, although the operation will be unprofitable, it will be aimed at making a profit in the future.

In practical terms, the doctrine of "business purpose" is revealed in such cases where the actions of the taxpayer deliberately have no other purpose than to reduce the tax burden. For example, carrying out unprofitable operations as an interdependent business entity in order to reduce the base of taxation. Proceeding from the doctrine of "business purpose", one should proceed to the definition of actions that termed as tax evasion.

\section{Ways of tax evasion}

Tax evasion refers to financial and economic operations that do not have a business purpose but are aimed at obtaining unwarranted tax benefits. The evasion of taxation involves the construction of specific models of financial and economic activity, accounting and tax accounting, and documenting economic turnover. An unreasonable tax benefit can be obtained through a tax deduction, tax evasion, and unlawful tax reimbursement from the budget. Therefore, it is possible to formulate a definition of a scheme for evading the budget.

The scheme of tax evasion is a set of financial and economic activities and their display in the documentary of the payer of taxes intended to receive unreasonable tax benefits in the absence of a "business purpose". This is a typical set of actions to avoid taxation with minor changes, which is often used by taxpayers. An analysis of the guidance materials of the state fiscal service and publications on minimizing the tax burden demonstrates a significant variety of schemes for tax evasion (Golovchenko, 2015). For example, in the information base of the fiscal services of Odessa, data on 190 patterns of tax evasion have been collected. Such a variety of actions of unscrupulous taxpayers complicates the identification and prosecution of tax evaders.

At the same time, among the applied schemes, it is possible to allocate a sufficient number of template actions for evading taxation. Many schemes use the same principles for concealing the taxable base and the schemes themselves are distinguished by minor nuances that are often due to the organizational and legal form, sectoral and regional specifics of the activity of taxpayers. In spheres that are not connected with taxation, shadow economic activity is carried out by means of evasion from public norms, rules, obligations.

There are many examples of such actions, for example, doing business without licenses, copyright infringement. These operations combine the existence of evasion of certain financial obligations or from the performance of compulsory actions, the implementation of costs. Evasion provides a kind of "economy" and, as a result, an unreasonable gain. Evasion is impossible without deliberate distortion or concealment of facts that are significant for the emergence of obligations. Such actions are distinguished by a variety of forms that are constantly changing and improved by persons who carry out shadow economic activities, with the aim of complicating the identification of the true meaning of operations. Disclosure of actual information about the nature of the shadow economic operation should lead to imposing sanctions on the business entity that carries out these operations.

\section{Classification of forms of shadow economic activity}

Economic evasion from social norms, rules, and obligations is a set of financial and economic operations and their display in the document circulation of an economic entity aimed at obtaining unreasonable benefits. At the same time, deliberately distorted or hidden facts that are important for the emergence of obligations to the state or other economic entities. The variety of actions for economic evasion complicates the identification and bringing to justice of organizers of shadow economic operations. In the meantime, among the methods that are applied, a lot of template actions can be distinguished. Based on the analysis of guidance documents and publications on identified economic and tax violations, such criteria were formulated for grouping ways of avoiding public norms, rules, and obligations (Fig. 2).

The classification is focused on identifying schemes, which are used by business entities. The criteria for grouping the composition of participants take into account the fact that, usually, evasion schemes are implemented through specific counterparties.

Participation in the operations of interdependent flyby-night companies (enterprises that were created for fictitious operations), offshore structures are one of the indicators of the possible application of the scheme of evasion by the business entity. The classification criteria from the "form of operations" group, which are used to conceal or distort information, must be constantly updated.

In order to complicate the detection of deviations, unscrupulous entrepreneurs constantly modify and find new ways of hiding or distorting information, often using the instability of Ukrainian legislation.

The actualization of classification characteristics should be carried out on the basis of systematization of the results of monitoring work. The classification has as its goal the development of unified methodological bases for identifying shadow economic activity in various spheres. The proposed classification will also ensure the creation of a data basis structure for preventing evasion of public norms, rules, and elements, which will effectively counteract the shadow manifestations in economic activities and, as a consequence, strengthening of the country's economic security. 


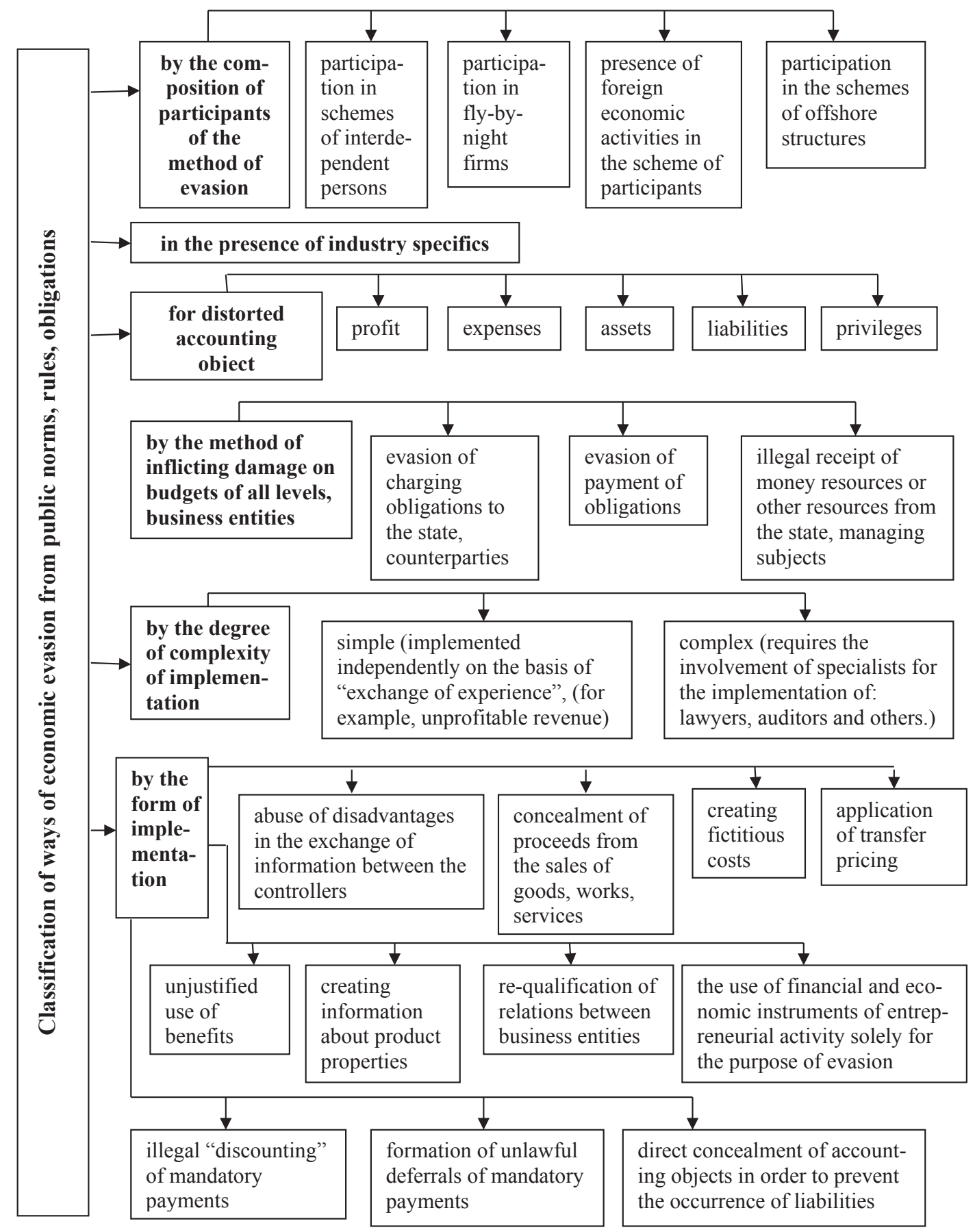

Fig. 2. Classification of ways of economic evasion from public norms, rules, obligations

Source has been elaborated by the author

With their help, information support can be provided for making decisions on conducting control measures.

\section{Conclusions}

As a result of the research, two types of shadow economy are identified.

The first type is the shadow economy as an independent sector of the economy, with an individual production function different from the official economy. This type of shadow economy is typical, mainly for the commandadministrative system and for the economy of poor countries, in a number of cases it can be observed in a developed market economy.

The second type of shadow economy can be observed in the market environment and it is a hidden version of the official economy with an identical production function. The main difference is in the external social 
environment, which under the influence of a group of factors forms a number of conditions for the functioning of shadow activities.

The external and internal conditions of functioning of the shadow and official economy are investigated and their classification is proposed.

Systematization of the ways of transferring resources to the shadow turnover is carried out, which is based on the model of the functioning of the business entity in the business environment.

Depending on the stage of the process of economic activity, ways of transferring resources to the shadow turnover that arise in the production process, as well as in the implementation of input and output commodity and financial flows, are identified.

The sources of information that characterizes the shadow activity are also investigated.

The transfer of resources to the shadow economy in case of tax evasion is carried out using tax evasion schemes.

The doctrine of "business purpose" is proposed, which consists in the fact that an operation aimed solely at reducing taxes, and not any other economically justified or economic goal, can be recognized as invalid.

Among the shadow schemes that are used to evade taxation, similar principles are singled out for concealing the taxable base.

Based on the analysis of instructive documents and publications on identified economic and tax violations, criteria are formulated for grouping ways of avoiding public norms, rules, and obligations: the composition of participants in the methods of evasion; the presence of specificity in the types of economic activity; distortion of the accounting object; ways of causing damage; degree of complexity of implementation; forms of operations used to distort information.

The developed classification will allow structuring databases on ways of evasion from taxation and transfer of economic resources to shadow turnover.

Practical application of the proposed classification will greatly simplify the information interaction between structures that oppose the shadow economy, which will allow more purposeful implementation of counteraction to shadow economic transactions as an institutional threat to economic security.

\section{References:}

Gerasimchuk Z.V., Vavidyuk N.S. (2006) Ekonomichna bezpeka rehionu: diahnostyka ta mekhanizm zabezpechennya [The economic security of the region: diagnostics and mechanism of its ensuring]. Lutsk: Nastirya. (in Ukrainian) Golovanov N.M., Perekislov V.E., Fadeyev V.A. (2003) Tenevaya ékonomika i legalyzatsyya prestupnykh dokhodov [The shadow economy and legalization of criminal incomes]. St. Petersburg : Peter. (in Russian)

Golovin S.D. (1992) O klassyfykatsyy yavleniy tenevoy ékonomiki [On the classification of phenomena of the shadow economy]. Vestnik MGU. Series: The Economy, no. 1, pp. 40-46. (in Russian)

Efremov K.I. Georgadze E.I. (2002) Voprosy otsenki ékonomycheskoy bezopasnosti regiona [Issues of assessing the economic security of the region]. Problems of Statistics, no. 2, pp. 57-59.

Zlupko S.M. (1996) Ukrayinska rehionalistyka: tendentsiyi, zdobutky, problemy [Ukrainian regionalism: trends, achievements, problems]. Regional Economics, no. 1, pp. 124-131.

Grossman G. (1977) The "Second economy" of the USSR. Problems of communism. - Wash., vol. 26, no. 5, pp. 25-40.

Boulding K. (1947) A Note of the Theory of the Black Market. Canadian Journal of Economics and Political Science,vol. 13, no. 1, pp. 115-118.

Tarasova I.I. (2014) Doslidzhennya teoriyi instytutsionalizmu v upravlinni ekonomichnymy ta suspilnymy instytutamy [Investigation of the theory of institutionalism in the management of economic and social institutions]. Scientific Journal "Economic Journal - XXI", no 11, pp. 11-14. (in Ukrainian)

Golovchenko O.M. (2015) Systema otsinky ekonomichnoyi bezpeky rehioniv v suchasnykh sotsialno-ekonomichnykh umovakh [The system of assessing the economic security of the regions in modern socio-economic conditions]. Prosseding of the Kontseptualni zasady ekonomichnoho $i$ pravovoho zabezpechennya bezpeky derzhavy $v$ umovakh yevrointehratsiyi (Ukrain, Odessa-Cherkasy, April 28-29, 2015), Odesa: ODUVS, 2015, pp. 24-28. (in Ukrainian) 